\title{
IMPACT OF EDUCATION ON PAIN AND QUALITY OF LIFE OF PATIENTS WITH RHEUMATOID ARTHRITIS - A PILOT STUDY
}

Ana Leticia Fontes de Oliveira Marcelino ${ }^{1}$, Lorena Costa Duval Borges² ${ }^{2}$ Lidia Assis Chaves² ${ }^{2}$ Caio Carvalhais Chaves ${ }^{1}$, João Victor de Pinho Costa ${ }^{1}$, Anderson Ramos Lisboa ${ }^{1}$, Urias Paulo Furquim Junior ${ }^{3}$, Tamires Rodrigues Pimentel da Silva ${ }^{1}$, Vivian Guerra de Faria ${ }^{1}$, Laura Cristine Carmo da Silva ${ }^{1}$, Liliane Morais Amara'11, Junia Amorim Andrade ${ }^{1}$, Ricardo Cruz Lage ${ }^{1}$, Maria Raquel da Costa Pinto ${ }^{1}$, Maria Fernanda Brandao Resende Guimarães ${ }^{1}$, Adriana Maria Kakehasi ${ }^{1}$, Débora Cerqueira Calderaro ${ }^{1, *}$

1.Universidade Federal de Minas Gerais, Belo Horizonte (MG), Brazil. 2. Centro Universitário de Belo Horizonte, Belo Horizonte (MG), Brazil. 3. Universidade Estadual do Rio de Janeiro (RJ), Brazil.

*Corresponding author: dccalderaro@gmail.com

\section{BACKGROUND}

Rheumatoid arthritis (RA) is an autoimmune, systemic disease characterized by chronic peripheral synovitis and extra-articular manifestations. It can lead to a decrease in functional independence, work capacity, and quality of life, partly due to pain and joint deformities. To minimize these functional losses, in addition to drug treatment, rehabilitation and patient education measures are necessary. Group intervention models have been suggested as a good strategy in the education of these patients.

\section{METHODS}

Groups of 8 to 12 patients were conducted in weekly meetings in sessions lasting 2 hours/week for 12 weeks, on the university hospital from August 2018 to June 2019. Educational actions were carried out through projected theoretical expositions [informative classes about the disease, its treatment, joint protection measures (JP), energy conservation (EC), and therapeutic exercises]. Practices with collective and individual orientations were also performed. In the first and last meetings of the group, the perception of pain reported by the patient on a visual analog scale (VAS pain) and the quality of life assessed by the descriptive system in three levels of five dimensions of EuroQol (EuroQoL5D3L) and its visual scale were evaluated analog (EQ-VAS).

\section{RESULTS}

In this analysis, 15 participants from the orientation groups, with participation in the meetings exceeding $80 \%$, were included. Fourteen patients (93\%) were female, with a mean age (SD) of 61.3 (9.3) years and mean time (SD) of RA duration of 19.9 (10.3) years. The majority (93\%) were using RA-modifying drugs, but the median DAS-28- PCR (3.07) showed moderate RA activity. Thirteen (87\%) patients already had joint deformities in their hands due to RA. After participation in the groups, there was a tendency to reduce pain and improve quality of life, as assessed by the EQ-5D-3L index and EQVAS, without statistical significance $(p>0.05)$. Despite the low number of patients included in this pilot study, a significant improvement was observed with the EQ-5D-3L domain regarding personal care $(p=0.046)$. During their participation in the groups, all patients reported the adoption of EC or JP measures in their daily routine and great satisfaction with the activities developed.

\section{CONCLUSION}

Patient education aims to increase the patients' knowledge about their disease and make them take a more active role in their treatment. The participation of RA patients in education groups was well accepted and contributed to the improvement in their selfperception of pain and quality of life.

\section{ACKNOWLEDEGMENTS}

We thank the multidisciplinary team at the Clinics Hospital of the Federal University of Minas Gerais (EBSerH/HC-UFMG) for their support. 


\section{FUNDING}

Programa de Apoio a Doutores recém-contratados 2019 - Universidade Federal de Minas Gerais.

\section{REFERENCES}

Borges et al. Impacto da educação na saúde de pacientes com artrite reumatoide - Estudo piloto. Cadernos de Terapia Ocupacional da USP. Forthcoming.

Noordhoek J, Loschiavo FQ. Intervenção da terapia ocupacional no tratamento de indivíduos com doenças reumáticas Utilizando a Abordagem da Proteção Articular. Rev Bras Reumatol. 2005;45(4):242-44. https://doi.org/10.1590/S0482-50042005000400008

Noordhoek J, Matias FM. Cartilha de Orientação aos Indivíduos Acometidos por Doenças Reumáticas. Belo Horizonte: Editora Gráfica Silveira; 2003.

Table 1. Characteristics of the patients included in this pilot study.

\begin{tabular}{cc}
\hline Female gender $^{*}$ & $14(93 \%)$ \\
\hline White color $^{*}$ & $3(20 \%)$ \\
\hline Age (years) $^{* *}$ & $61.27(9.25)$ \\
\hline Monthly family income\& $^{*}$ & $2.0(1.26)$ \\
\hline RA duration (years) & $19.93(10.31)$ \\
\hline Positive RF $^{* *}$ & $9(69 \%)$ \\
\hline ACPA positive $^{2}$ & $5(62,5 \%)$ \\
\hline Joint deformities in hands ${ }^{*}$ & $13(87 \%)$ \\
\hline${\text { Radiographic change in } \text { hands }^{* 3}}^{*}$ & $11(100 \%)$ \\
\hline DAS28-CRP & $3.04(1.7)$ \\
\hline Prednisone use & $3(20 \%)$ \\
\hline Use of disease-modifying drugs & $14(93 \%)$ \\
\hline
\end{tabular}

RA: Rheumatoid arthritis. RF: rheumatoid factor. ACPA: anticitrullinated protein antibody. DAS28-PCR: Disease Activity Score using a 28-joint count and C-reactive protein. "Boutonniere or swan neck deformities of fingers, ulnar deviation of the metacarpophalangeal joints or Z-shaped deformity of the thumbs. ${ }^{1}$ Results for the rheumatoid factor were available for the 13 patients. ${ }^{2}$ The ACPA result was available for 8 patients. ${ }^{3}$ Description of radiographs of the hands were reported in the medical records of 11 patients. The presence of erosions or juxta-articular rarefaction were considered suggestive of RA. "Absolute value (\%). "Average (DP). ${ }^{8}$ Median (interquartile range).

Source: BORGES, LCD; 2020

Table 2. Comparative analysis of included variables at the beginning (T0) and after completion of participation at the groups (T1).

\begin{tabular}{cccc}
\hline Variable & T0 & T1 & P-value \\
\hline Pain VAS $(\mathrm{mm})^{* *}$ & $54.58(30.26)$ & 42.5 & 0.13 \\
\hline EQ-5D-3L* $^{* *}$ & $0.620(0.174)$ & $0.631(0.235)$ & 0.28 \\
\hline EQ5D Mobility\& $^{\&}$ & $2.0(1.0)$ & $2.0(1.0)$ & 1,0 \\
\hline EQ5D Self-care $^{\&}$ & $2.0(1.0)$ & $1.0(1.0)$ & $0.046^{*}$ \\
\hline EQ5D Usual activities $^{*}$ & $2.0(1.0)$ & $2.0(1.0)$ & 0.32 \\
\hline EQ5D Pain/Discomfort $^{\&}$ & $2.0(1.0)$ & $2.0(1.0)$ & 0.56 \\
\hline EQ5D Anxiety/depression $^{\&}$ & $2.0(1.0)$ & $2.0(1.0)$ & 1.0 \\
\hline EQ5D VAS* & $70.42(17.1)$ & $73.33(18.25)$ & 0.25 \\
\hline
\end{tabular}

